\title{
Folic Acid Status and Associated Factors for Pregnant Chinese Women - China, 2015
}

\author{
Shan Jiang'; Jie Wang'; Yifan Duan'; Xuehong Pang'; Ye Bi' ${ }^{1}$; Huanmei Zhang ${ }^{1}$; Shuxia Wang'; Zhenyu Yang ${ }^{1, *}$
}

\section{Summary}

What is already known on this topic?

Low folate status in pregnancy has been associated with multiple adverse pregnancy outcomes, including neural tube defects, congenital heart defects, fetal growth restriction, low birth weight, and preterm delivery. Low folate status is common in China, especially in northern areas.

What is added by this report?

Folate status remains suboptimal among pregnant Chinese women in 2015. Folate concentration was in the widespread in rural area $(9.88 \mathrm{ng} / \mathrm{mL})$ and especially in the northern of China $(9.10 \mathrm{ng} / \mathrm{mL})$. Pregnant women in the last trimester had the lowest folic acid concentration $(9.18 \mathrm{ng} / \mathrm{mL})$. Taking folic acid supplements every day would achieve adequate serum folate concentrations $(10.87 \mathrm{ng} / \mathrm{mL} v$ s. $10.11 \mathrm{ng} / \mathrm{mL} v$ s. $9.38 \mathrm{ng} / \mathrm{mL}, P<0.001)$.

What are the implications for public health practice?

Folic acid interventions should be strengthened, especially for pregnant women in rural areas and in northern China, those with junior school or below education, those pregnant during spring and winter, or those with late pregnancy.

Folate is an essential element for DNA replication and normal cell formation and growth, and it is particularly critical during the early stages of human embryo development. Low folate levels during pregnancy is associated with multiple adverse pregnancy outcomes including neural tube defects (NTD). Low folate status is common in China, especially in northern China. However, most studies on folate status focused on specific regions and women of childbearing age, and few studies have been conducted on the folate status of pregnant women in China. Several studies found that living in northern areas, living in rural areas, and being in early lactating periods were risk factors associated with folic acid deficiency in lactating women, where folic acid interventions should be considered as a priority. The Ministry of Health of China (now the National Health Commission; NHC) launched a nationwide program to increase folic acid intake in rural reproductive-aged women starting in 2009. This program provided folic acid supplements $(0.4 \mathrm{mg}$ folic acid per tablet) for free to women with rural household registrations and who intended to get pregnant. Significant developments have occurred in pregnant women's dietary habits, economic status, and educational level. This study aimed to observe the folic acid status and associated factors of Pregnant Chinese women in 2015.

The data of pregnant women were extracted from the China Nutrition and Health Surveillance (2015-2017). By using a multistage stratified cluster random sampling method, 30 pregnant women were sampled from each of 302 sites in 31 provincial-level administrative divisions (PLADs) of the mainland of China. After excluding those without adequate blood specimens, data of birth, or gestational weeks, 7,985 pregnant women were included in the analysis. This project has been approved by the Ethics Review Committee of the Institute of Nutrition and Health of China CDC (Number: 201519-A). All respondents have signed informed consent before the investigation.

A standard questionnaire was used to obtain general information, history of pregnancy, and folic acid supplements. A $4 \mathrm{~mL}$ fasting blood sample was collected from each individual and stored in a $-80{ }^{\circ} \mathrm{C}$ freezer. Serum folate concentration was measured by the electro-chemiluminescence immunoassay method (Elecsys Folate III, Cobas 601 Roche). A high and a low-quality control material (Elecsys Precicontrol Varia, Roche) were entered on each run and the target value $($ Mean $\pm 3 S D)$ was $(2.87 \pm 1.29) \mathrm{ng} / \mathrm{mL}$ and $(11.1 \pm 3.0) \mathrm{ng} / \mathrm{mL}$, respectively. The results of the test quality material were expressed as the following means: High 11.70 (SD 1.36) $\mathrm{ng} / \mathrm{mL}$ and Low 3.17 (SD $0.39) \mathrm{ng} / \mathrm{mL}$; the coefficient of variation (CV) of high and low-quality control material was $12.2 \%$ and 
$11.6 \%$, respectively.

Multiple linear regressions were utilized to examine the relationship between serum folate concentration and various variables. The stepwise selection was applied to select independent variables [e.g., education, gestation, season, body mass index (BMI), age, and folic acid supplementation], adjusting for regions as well as for potential sociodemographic characteristics that were associated with serum folate. The $\mathrm{F}$ test and coefficient of determination $\mathrm{R}^{2}$ were used to identify the optimal model. Folic acid deficiency was defined as a serum folic acid level $<2 \mathrm{ng} / \mathrm{mL}(4.53 \mathrm{nmol} / \mathrm{L})$ recommended by US CDC (1). Statistical significance was established at $P<0.05$ for all analysis. All data cleaning and statistical analyses were performed using SAS software (version 9.4, SAS Institute Inc., Cary, NC, USA).

A total of 7,985 pregnant women were included in the study, and the mean age of subjects was $27.9 \pm 4.6$ years old. More than half of the pregnant women were living in cities $(56.4 \%)$ and completed high school or above education level $(63.0 \%), 88.5 \%$ were Han nationality, and $37.1 \%$ were unemployed or stayed at home (Table 1).

TABLE 1. Association between characteristics and serum folate concentrations $(\mathrm{ng} / \mathrm{mL})$ of pregnant women — China, 2015.

\begin{tabular}{|c|c|c|c|c|}
\hline Variable & $\mathbf{N}$ & Serum folate $(\mathrm{ng} / \mathrm{mL}) \mathbf{P}_{50}\left(P_{25}-P_{75}\right)$ & $x^{2}$ & $P$ \\
\hline Age (years) & & & 56.73 & $<0.001$ \\
\hline$<25$ & 2,137 & $7.14(4.28-11.82)$ & & \\
\hline $25-34$ & 5,229 & $8.36(4.93-13.01)$ & & \\
\hline$\geq 35$ & 619 & $8.62(4.96-13.75)$ & & \\
\hline Nationality & & & 28.35 & $<0.001$ \\
\hline Han & 6,945 & $8.27(4.93-13.00)$ & & \\
\hline Minority & 902 & $6.44(3.54-10.87)$ & & \\
\hline Missing & 138 & & & \\
\hline Gestational weeks & & & 359.12 & $<0.001$ \\
\hline$<12$ & 2,217 & $10.40(6.27-14.65)$ & & \\
\hline $13-27$ & 3,001 & $8.01(4.87-12.50)$ & & \\
\hline$\geq 28$ & 2,654 & $6.56(4.04-10.83)$ & & \\
\hline Missing & 113 & & & \\
\hline BMI & & & 183.11 & $<0.001$ \\
\hline$\leq 18.5$ & 406 & $10.55(6.16-14.42)$ & & \\
\hline $18.5-23.9$ & 3,579 & $9.00(5.28-13.52)$ & & \\
\hline $24.0-27.9$ & 2,557 & $7.24(4.40-12.06)$ & & \\
\hline$\geq 28.0$ & 1,325 & $6.72(4.03-11.04)$ & & \\
\hline Missing & 118 & & & \\
\hline Education & & & 229.74 & $<0.001$ \\
\hline Junior high and below & 2,953 & $6.91(4.10-11.30)$ & & \\
\hline Senior high/college & 3,561 & $8.36(4.85-12.98)$ & & \\
\hline University and above & 1,471 & $10.22(5.93-14.46)$ & & \\
\hline Occupation & & & 252.45 & $<0.001$ \\
\hline Agriculture, forestry, animal husbandry, fishery & 907 & $5.72(3.14-9.37)$ & & \\
\hline $\begin{array}{l}\text { Production and transportation equipment operators, } \\
\text { commercial service personnel }\end{array}$ & 1,043 & $8.63(5.06-12.97)$ & & \\
\hline $\begin{array}{l}\text { State organs, party-mass organizations, enterprises } \\
\text { and public institutions, working, personnel }\end{array}$ & 1,013 & $9.72(5.55-14.03)$ & & \\
\hline Professionals & 1,465 & $8.99(5.41-13.68)$ & & \\
\hline Other workers & 532 & $8.35(5.30-12.63)$ & & \\
\hline Students and unemployed & 2,923 & $7.79(4.62-12.41)$ & & \\
\hline Missing & 102 & & & \\
\hline
\end{tabular}


TABLE 1. (Continued)

\begin{tabular}{|c|c|c|c|c|}
\hline Variable & $\mathbf{N}$ & Serum folate $(\mathrm{ng} / \mathrm{mL}) P_{50}\left(P_{25}-P_{75}\right)$ & $x^{2}$ & $P$ \\
\hline Area type & & & 85.56 & $<0.001$ \\
\hline Urban & 4,450 & $8.62(5.36-13.25)$ & & \\
\hline Rural & 3,446 & $7.41(4.15-12.29)$ & & \\
\hline Missing & 89 & & & \\
\hline Region & & & 398.41 & $<0.001$ \\
\hline Northern region & 3,785 & $6.52(3.73-11.44)$ & & \\
\hline Southern region & 4,200 & $9.28(5.86-13.72)$ & & \\
\hline Tine since last pregnancy (years) & & & 14.38 & $<0.01$ \\
\hline$<1$ & 4,017 & $8.19(4.92-13.17)$ & & \\
\hline $1-5$ & 602 & $7.88(4.39-12.36)$ & & \\
\hline$>5$ & 3,366 & $7.86(4.57-12.41)$ & & \\
\hline Folic acid supplementation & & & 185.65 & $<0.001$ \\
\hline Yes & 6,861 & $8.43(4.98-13.18)$ & & \\
\hline No & 1,021 & $5.84(3.48-9.63)$ & & \\
\hline Missing & 103 & & & \\
\hline Timing of folic acid supplementation & & & 9.47 & 0.002 \\
\hline After pregnancy & 3,476 & $8.18(4.95-12.80)$ & & \\
\hline Before pregnancy & 3,393 & $8.77(5.01-13.54)$ & & \\
\hline Missing & 1,116 & & & \\
\hline Supplementation frequency in the past week (days) & & & 317.43 & $<0.001$ \\
\hline$\leq 3$ & 3,283 & $7.14(4.37-11.28)$ & & \\
\hline $3-6$ & 686 & $8.93(5.42-13.56)$ & & \\
\hline 7 & 2,892 & $10.35(6.01-14.73)$ & & \\
\hline Missing & 1,124 & & & \\
\hline Season & & & 52.17 & $<0.001$ \\
\hline Spring & 977 & $6.73(3.33-12.15)$ & & \\
\hline Summer & 33 & $12.17(6.14-15.17)$ & & \\
\hline Autumn & 1,251 & $8.47(5.36-12.78)$ & & \\
\hline Winter & 5,185 & $8.02(4.73-12.79)$ & & \\
\hline Missing & 450 & & & \\
\hline
\end{tabular}

Abbreviation: $\mathrm{BMI}=$ body mass index.

The median (25th and 75th percentiles) serum folate concentrations were $8.02(4.73-12.79) \mathrm{ng} / \mathrm{mL}$. Overall, $6.12 \%$ of pregnant women were folate deficient. As presented in Table 2, compared with those living in the rural, pregnant women living in urban had a significantly higher serum concentration $(9.88 \mathrm{ng} / \mathrm{mL}$ vs. $10.37 \mathrm{ng} / \mathrm{mL}, P<0.001)$. Compared with those living in the northern region, pregnant women living in the southern region had a higher serum folate concentration $(9.10 \mathrm{ng} / \mathrm{mL}$ vs. $11.14 \mathrm{ng} / \mathrm{mL}$, $P<0.001)$. Pregnant women in the first trimester and second trimester had higher folic acid concentration than those in the last trimester $(11.13 \mathrm{ng} / \mathrm{mL}$ and
$10.05 \mathrm{ng} / \mathrm{mL}$ vs. $9.18 \mathrm{ng} / \mathrm{mL}, P<0.001)$. Serum folate status in summer and autumn were higher than the other 2 seasons $(12.07 \mathrm{ng} / \mathrm{mL}$ and $10.01 \mathrm{ng} / \mathrm{mL}$ vs. $8.76 \mathrm{ng} / \mathrm{mL}$ and $9.63 \mathrm{ng} / \mathrm{mL}, P<0.001)$. Pregnant women who took folic acid supplements every day had highest serum folate concentration than those who did not $(10.87 \mathrm{ng} / \mathrm{mL}$ vs. $10.11 \mathrm{ng} / \mathrm{mL}$ vs. $9.38 \mathrm{ng} / \mathrm{mL}$, $P<0.001)$. Compared with normal weight pregnant women, obese pregnant women have lower levels of folate status $(9.66 \mathrm{ng} / \mathrm{mL}$ vs. $10.04 \mathrm{ng} / \mathrm{mL}, P<0.001)$. The older ( $>25$ years) pregnant women and with higher levels of education have the higher serum folate concentration $(10.16 \mathrm{ng} / \mathrm{mL}$ vs. $10.54 \mathrm{ng} / \mathrm{mL}$ vs. 
TABLE 2. Factors are associated with serum folate of pregnant women - China, 2015.

\begin{tabular}{|c|c|c|c|}
\hline Risk factors & LSMEAN (ng/mL) & SE & $\operatorname{Pr}>|t|$ \\
\hline \multicolumn{4}{|l|}{ Residence } \\
\hline Urban & 10.37 & 0.27 & \\
\hline Rural & 9.88 & 0.28 & $<0.001$ \\
\hline \multicolumn{4}{|l|}{ Region } \\
\hline Northern region & 9.10 & 0.27 & \\
\hline Southern region & 11.14 & 0.28 & $<0.001$ \\
\hline \multicolumn{4}{|c|}{ Supplementation frequency in the past week (days) } \\
\hline$\leq 3$ & 9.38 & 0.28 & \\
\hline $3-6$ & 10.11 & 0.32 & $<0.001$ \\
\hline 7 & 10.87 & 0.27 & $<0.001$ \\
\hline \multicolumn{4}{|l|}{ Gestational weeks } \\
\hline$<12$ & 11.13 & 0.29 & \\
\hline $13-27$ & 10.05 & 0.28 & $<0.001$ \\
\hline$\geq 28$ & 9.18 & 0.28 & $<0.001$ \\
\hline \multicolumn{4}{|l|}{ Season } \\
\hline Spring & 8.76 & 0.20 & \\
\hline Summer & 12.07 & 0.97 & $<0.001$ \\
\hline Autumn & 10.01 & 0.18 & $<0.001$ \\
\hline Winter & 9.63 & 0.13 & $<0.001$ \\
\hline \multicolumn{4}{|l|}{ BMI } \\
\hline$\leq 18.5$ & 10.99 & 0.39 & 0.002 \\
\hline $18.5-23.9$ & 10.04 & 0.27 & \\
\hline $24.0-27.9$ & 9.78 & 0.28 & $<0.074$ \\
\hline$\geq 28.0$ & 9.66 & 0.30 & $<0.041$ \\
\hline \multicolumn{4}{|l|}{ Age (years) } \\
\hline$<25$ & 9.56 & 0.28 & \\
\hline $25-34$ & 10.16 & 0.26 & $<0.001$ \\
\hline$\geq 35$ & 10.54 & 0.33 & $<0.001$ \\
\hline \multicolumn{4}{|l|}{ Education* } \\
\hline Junior high and below & 9.44 & 0.28 & \\
\hline Senior high/college & 10.01 & 0.28 & $<0.001$ \\
\hline University and above & 10.91 & 0.29 & $<0.001$ \\
\hline
\end{tabular}

Abbreviation: BMl=body mass index; LSMEAN=least squares means; SE=standard error.

*Junior high and below: include that do not receive formal school education; do not graduate from primary school; graduate from primary school; graduate from junior high school. Senior high/college: include high school; technical secondary school; technical school; graduate from college. University and above: include that graduated from the university, get a master degree, or above.

$9.56 \mathrm{ng} / \mathrm{mL}, P<0.001),(10.01 \mathrm{ng} / \mathrm{mL}$ vs. $10.91 \mathrm{ng} / \mathrm{mL}$ vs. $9.44 \mathrm{ng} / \mathrm{mL}, P<0.001)$.

\section{DISCUSSION}

In this study, the prevalence of folic acid deficiency was $6.12 \%$ for pregnant women in China. A study conducted in Shanxi Province found that the median folic acid level was $7.6 \mathrm{ng} / \mathrm{mL}(2)$, which was close to our results. Furthermore, in more developed countries such as the United States $(14.9 \mathrm{ng} / \mathrm{mL})$ and New Zealand $(21.4 \mathrm{ng} / \mathrm{mL})$, the mean serum folic acid levels were higher than the results demonstrated in this study (3-4).

The serum folate level of pregnant women was higher in urban areas than in rural areas in this study. 
Despite the implementation of the free folic acid supplementation programs in rural area, the status of serum folic was still significantly lower than that of urban areas. On the other hand, a study conducted by Zhu L, et al. (5) showed that 32\%-35\% of women had low plasma folate $(5.2 \mathrm{ng} / \mathrm{mL})$. In this study, pregnant women living in northern regions still had a lower folate concentration.

Maternal age, education levels, and gestation were associated with folate concentrations in pregnancy. Pregnant women of older ages ( $>25$ years) and higher levels of education have the higher serum folate concentration. This suggested that pregnant women of older ages ( $>25$ years) and higher education may pay more attention to prepare for pregnancy and achieve adequate nutritional status during gestation.

It has been previously observed that folic acid supplementation had a strong impact on serum folate concentrations (FA). Liu J et al. (G) found that earlier supplementation, increase in supplementation frequency, and more total days of supplementation were associated with higher plasma folate concentrations. The results also revealed that pregnant women who took folic acid supplements every day had the highest serum folate concentration than other pregnant women. Studies on later pregnancies showed the importance of continued FA supplementation $(0.4 \mathrm{mg} / \mathrm{d})$ in the second and third trimesters ( 7$)$. Taking FA supplement may prevent declines in serum and erythrocyte folate concentrations and increase plasma homocysteine concentration, which occurs as pregnancy progresses. Therefore, the nationwide program should further emphasize the timing and frequency of supplementation.

The usage, number, and type of supplements changed throughout pregnancy. Looman $\mathrm{M}$ et al. (8) found that plasma folate levels significantly increased from preconception to 12 gestational weeks and were significantly lower in 24 gestational weeks. This drop is most likely related to the intake of folic acid supplements until week 12 of gestation. The drop in supplemental folate intake from week 12 to 24 of pregnancy has also been observed in numerous studies (9). The study further demonstrated that serum folate levels in the second and the third trimester was significantly lower than the first trimester.

According to the study in Anhui Province, folate concentration in summer and autumn was higher than in other seasons (10), equally this study showed that the serum folate status of pregnant women in the summer and autumn were higher than in other seasons. The main resource of folate is provided by the consumption of dark-green leafy vegetables (e.g., lettuce, spinach, and broccoli) since people seldom fortify food with folic acid in China. However, compared with other seasons, dark-green leafy vegetables were less available in spring and winter.

Similar to the study of Cheng TL et al. (11), a significantly lower folate level was found in obese groups compared with other BMI groups. This indicated that obesity might influence folate metabolism and ideal folate levels should be measured before conception so that personalized advice can be provided.

This study was subject to some limitations. First, the sample size used in the study was small in each study site, and participants were recruited from prenatal care clinics, which may not represent the whole country. Women who sought prenatal care (and thus were recruited into the study) may differ from others in terms of socioeconomic and demographic status, which might affect the generalization of the current results. Second, serum folic acid is heavily affected by recent folate intake including dietary folic acid and supplementary folate intake. If red blood cell folate levels were measured, we could have a better understanding of overall folate status.

Funding: National Health and Family Planning Commission (former Ministry of Health of the People's Republic of China) Medical Reform Major Program: Chinese Nutrition and Health Surveillance (2015).

\section{doi: $10.46234 / \mathrm{ccdcw} 2021.065$ \\ \# Corresponding author: Zhenyu Yang, yangzy@ninh.chinacdc.cn.}

\begin{abstract}
${ }^{1}$ National Institute for Nutrition and Health, Chinese Center for Disease Control and Prevention; Key Laboratory of Trace Element Nutrition, National Health and Family Planning Commission of the Peoples' Republic of China, Beijing, China.
\end{abstract}

Submitted: January 18, 2021; Accepted: March 10, 2021

\section{REFERENCES}

1. Pfeiffer CM, Sternberg MR, Schleicher RL, Haynes BMH, Rybak ME, Pirkle JL. The CDC's Second National Report on Biochemical Indicators of Diet and Nutrition in the U.S. Population is a valuable tool for researchers and policy makers. J Nutr 2013;143(6):938s - 47s. http://dx.doi.org/10.3945/jn.112.172858.

2. Du YJ, Li J, Wang HL, Du JY, Qu PF, Zhang R, et al. Epidemiological characteristics of serum vitamin B12 and folate levels in women awaiting delivery. Chin J Epidemiol 2020;41(8):1359-64. http://dx.doi.org/10.3760/cma.j.cn112338-20190927-00707. (In Chinese).

3. Bulloch RE, McCowan LME, Thompson JMD, Houghton LA, Wall CR. Plasma folate and its association with folic acid supplementation, 
socio-demographic and lifestyle factors among New Zealand pregnant women. $\mathrm{Br} \quad \mathrm{J}$ Nutr 2019;122(8):910 - 8. http://dx.doi.org/10. $1017 /$ S0007114519001788.

4. Marchetta CM, Hamner HC. Blood folate concentrations among women of childbearing age by race/ethnicity and acculturation, NHANES 2001-2010. Matern Child Nutr 2016;12(1):39-50. http://dx.doi.org/10.1111/mcn.12134.

5. Zhu L, Ling $\mathrm{H}$. National neural tube defects prevention program in China. Food Nutr Bull 2008;29(2 Suppl):S196 - 204. http://dx.doi.org/ $10.1177 / 15648265080292 S 123$.

6. Liu JF, Jin L, Meng QQ, Gao LL, Zhang L, Li ZW, et al. Changes in folic acid supplementation behaviour among women of reproductive age after the implementation of a massive supplementation programme in China. Public Health Nutr 2015;18(4):582 - 8. http://dx.doi.org/ $10.1017 /$ S1368980014000950.

7. McNulty B, McNulty H, Marshall B, Ward M, Molloy AM, Scott JM, et al. Impact of continuing folic acid after the first trimester of pregnancy: findings of a randomized trial of folic acid supplementation in the second and third trimesters. Am J Clin Nutr 2013;98(1):92 - 8 . http://dx.doi.org/10.3945/ajcn.112.057489.

8. Looman M, Geelen A, Samlal RAK, Heijligenberg R, Gunnewiek JMTK, Balvers MGJ, et al. Changes in micronutrient intake and status, diet quality and glucose tolerance from preconception to the second trimester of pregnancy. Nutrients 2019;11(2):460. http://dx.doi.org/ $10.3390 /$ nu1 1020460

9. Dubois L, Diasparra M, Bédard B, Colapinto CK, Fontaine-Bisson B, Morisset AS, et al. Adequacy of nutritional intake from food and supplements in a cohort of pregnant women in Québec, Canada: the 3D Cohort Study (Design, Develop, Discover). Am J Clin Nutr 2017;106(2):541 - 8. http://dx.doi.org/10.3945/ajcn.117.155499.

10. Xie QR, Fu SL, Guo F, Zhu YY, Su PY. Blood folic acid concentration and seasonal variations among progestational and pregnant women. Mod Prev Med 2015;42(1): 61-3, 71. http://d.wanfangdata.com. $\mathrm{cn} /$ periodical/xdyfyx201501021. (In Chinese).

11. Cheng TL, Mistry KB, Wang GY, Zuckerman B, Wang XB. Folate nutrition status in mothers of the boston birth cohort, sample of a US urban low-income population. Am J Public Health 2018;108(6):799 807. http://dx.doi.org/10.2105/ajph.2018.304355. 